\title{
Assessment of Some Scoring Systems in Prediction of Mortality in Acute Carbon Monoxide Poisoned Patients
}

\author{
Doaa M. El-Gharbawy ${ }^{1 *}$ and Heba K. Khalifa ${ }^{1}$
}

\begin{tabular}{|c|c|}
\hline & ABSTRACT \\
\hline $\begin{array}{l}\text { KEYWORDS } \\
\text { Glasgow coma scale, } \\
\text { Acute physiology and } \\
\text { chronic health evaluation II, } \\
\text { simplified acute physiology } \\
\text { score II, } \\
\text { rapid emergency medicine } \\
\text { score, } \\
\text { carbon monoxide poisoning, } \\
\text { prediction of mortality. }\end{array}$ & $\begin{array}{l}\text { Carbon monoxide (CO) is known as a silent killer. In Egypt, it is one of the most } \\
\text { common causes of death-related poisonings. This study aimed to evaluate some } \\
\text { scoring systems; Glasgow coma scale (GCS), acute physiology and chronic health } \\
\text { evaluation II (APACHE II), simplified acute physiology score II (SAPS II) and rapid } \\
\text { emergency medicine score (REMS) for predicting in-hospital mortality of patients } \\
\text { with acute CO poisoning. One hundred and eight acutely CO poisoned patients were } \\
\text { included in the study. For each patient, socio-demographic and toxicological data } \\
\text { were recorded. Clinical examination and calculation of the four scoring systems were } \\
\text { performed. Patients were divided into two groups; survivors and non-survivors. } \\
\text { Discrimination was evaluated using ROC curve and calculating the area under the } \\
\text { curve (AUC). The current study revealed that median age of the studied patients was } \\
25.5 \text { years, 55.6\% were males and } 61.1 \% \text { were from rural areas. All cases were } \\
\text { intoxicated accidently. Among the studied } 108 \text { patients; } 20 \text { patients died in hospital } \\
\text { and } 88 \text { patients survived. Both APACHE II and SAPS II had the best AUC, followed } \\
\text { by REMS then GCS. The AUC of GCS was significantly lower than those of } \\
\text { APACHE II, SAPS II and REMS scores; while differences between AUC of } \\
\text { APACHE II, SAPS, and REMS were not statistically significant. It could be } \\
\text { concluded that REMS is more useful in predicting in-hospital mortality in acute CO } \\
\text { poisoning as it is a simple, easy and rapid scoring system rather than more } \\
\text { complicated scoring systems such as APACHE II and SAPS II. }\end{array}$ \\
\hline
\end{tabular}

\section{Introduction}

Carbon monoxide (CO) is known as silent killer; since it is a colorless, odorless and non-irritating but highly toxic gas. It results from incomplete combustion of carbonaceous substances (Rose et al., 2017; Ng et al., 2018). It produces its most harmful effects in the highly oxygen demand organs such as brain and heart (Tabrizian et al., 2018).

\footnotetext{
${ }^{(1)}$ Forensic Medicine and Clinical Toxicology Department, Faculty of Medicine, Tanta University. Tanta, Egypt

*Correspondence to Doaa Mohamed El-Gharbawy, doaa.elgharbawy@yahoo.com
}

Carbon monoxide poisoning is considered one of the most common causes of poisoning related deaths worldwide. In the United States, about 2700 fatalities have been recorded each year (Neil and Hampson, 2011). In Iran, Nazari et al. (2010) reported that mortality rate after accidental $\mathrm{CO}$ poisoning was $11.6 \%$. Another retrospective study conducted by Aldossary et al. (2015) in Dammam, Kingdom of Saudi Arabia, studied the CO deaths from 2004 to 2013, and revealed that the rate of $\mathrm{CO}$ fatalities increased throughout the study period to reach its maximum incidence (22.08\%) in 2013. Whereas, in Egypt, the annual report of Poison Control Center (PCC), Ain Shams University Hospitals, Cairo, revealed that $\mathrm{CO}$ poisoning 
represented $1.5 \%$ out of 9762 non-drug poisoned cases received in PCC throughout 2011, also, it was the $3^{\text {rd }}$ cause of death-related poisonings recorded in this year (El-Masry and Tawfik, 2013).

Despite, high fatality rate of $\mathrm{CO}$ intoxication but, it is still considered one of the possibly predictable health-related conditions (Tabrizian et al., 2018). However, the ability to assess outcomes of patients admitted to emergency department is deemed as a challenging task, therefore, many scoring systems have been developed continuously to quantify the severity of diseases, their course and prognosis. Moreover, scoring systems may be used for assessing therapies and economical estimation of intensive care (Barghash et al., 2017). Among these scoring systems, the Glasgow coma scale (GCS), acute physiology and chronic health evaluation (APACHE II) score, rapid emergency medicine score (REMS) and simplified acute physiology score (SAPS II) have been used in clinical practice (Ha et al., 2015).

Glasgow coma scale (GCS) has been widely known in intensive care units (ICUs) and emergency pre-hospital settings as an effective tool for consciousness level assessment and prediction of patient's outcome (El-Sarnagawy and Hafez, 2017). While, the APACHE II score is one of the firstly proposed scoring systems that accomplished widespread use for predicti ng severity of disease and in-hospital mortality. Similarly, the SAPS II score was proposed by Le Gall et al. in (1993) and has been widely used by most ICUs to predict clinical outcome (Aminiahidashti et al., 2017).

However, APACHE-II and SAPS II scores are to some extent considered as complicated scoring systems. They demand some laboratory findings that may not be available early at the time of admission, which may interfere with their use in rapid scoring of patients in emergency department. Therefore, the REMS score has been developed as a simple and highly applicable scoring system for predicting outcome in patients admitted to emergency department. This could be attributed to the fact that the required input variables for REMS are easily and routinely available for all patients at admission (Ha et al., 2015; Alter et al., 2017).

These scoring systems have been compared in many studies that evaluating intoxicated patients (Kelly et al., 2004; EizadiMood et al., 2011; Kim et al., 2013), but have yielded some contradicting findings. Hence, this study was designed to evaluate four scoring systems; GCS, APACHE II, SAPS II and REMS for predicting in-hospital mortality of patients with acute carbon monoxide poisoning.

\section{Patients and Methods}

\section{Study design and ethical points:}

This prospective study was conducted throughout the period from Jan 2016 to June 2017 on one hundred and eight Egyptian patients of both sexes with acute carbonmonoxide (CO) poisoning admitted to Poison Control Center, Tanta Emergency Hospital. The study was performed after approval of Research Ethics Committee of Tanta Faculty of Medicine. Written informed consents were signed by adult conscious patients or relatives of kin for unconscious patients and teenagers. The privacy and confidentiality of the patients' data and records were maintained through coding system.

\section{Patients}

Patients of both sexes aged 16 years or more with acute carbon-monoxide poisoning 
admitted within 24 hours, during the study period, were recruited in the present study. Exclusion criteria included patients with past history of cardiovascular, neurological, respiratory, hepatic or renal disorders. Patients with history of co-ingestion of poisons, patients with risk factors such as hypertension, diabetes and smoking as well as patients transferred from other hospitals or admitted after 24 hours were also excluded. Diagnosis of acute CO poisoning based on history of $\mathrm{CO}$ exposure; characteristic clinical features of $\mathrm{CO}$ poisoning and increased serum level of carboxy hemoglobin at admission.

\section{Methods}

The following data was recorded for all patients, socio-demographic data (patient's code, age, gender, residence, and time of admission), poisoning data (source and duration of $\mathrm{CO}$ exposure, mode of poisoning, time elapsed between acute $\mathrm{CO}$ exposure and arrival to hospital "delay time"). Furthermore, patient's outcome including; recovery, complications or death, need for ICU admission, intubation and mechanical ventilation, and hospital stay duration were also recorded.

Complete physical examination and calculation of the four scoring systems (GCS, APACHE II, SAPS II and REMS) were performed for all patients at admission. Then patients were divided into two groups; survivors and non-survivors groups.

The GCS based on measuring three different components; eyes opening, verbal and motor responses (Table 1). Each component gives a range of numbers that correlate with certain levels of consciousness then the scoring points are collated and give a GCS between 3 (deep unconscious) to 15 (normal conscious level) (Teasdale and Jennett, 1974).
To calculate the APACHE II score, age and 12 common physiological and laboratory values were employed including body temperature, mean arterial pressure, pulse rate, respiratory rate, oxygenation of arterial blood, arterial $\mathrm{pH}$, serum sodium, serum potassium, serum creatinine, haematocrit, white blood cell count and GCS. The APACHE II score ranges from 0 to 71 (Knaus et al., 1985). Likewise, The SAPS II is composed of 17 variables; 12 physiological variables, type of admission (scheduled surgical, unscheduled surgical, or medical), age and three disease-related variables (acquired immunodeficiency syndrome, metastatic cancer, and hematologic malignancy). Its score ranges from 0 to 163 points (Le Gall et al., 1993).

The REMS is calculated easily by adding the score points of peripheral oxygen saturation and age to other four variables; GCS, mean arterial pressure, pulse rate, and respiratory rate. Each variable has a scoring range from 0 to 4 except age from 0 to 6 and the maximum score of REMS is 26 (Olsson et al., 2004a).

\section{Statistical analysis}

The collected data was statistically analyzed using MedCalc Statistical Software version 15.8. For quantitative data, the Shapiro-Wilk test for normality was performed. Numerical data did not follow normal distribution. Therefore, they were summarized as median and interquartile range (expressed as $25^{\text {th }}-75^{\text {th }}$ percentiles) and Mann-Whitney test was used to compare between two independent groups. Spearman's correlation was used to assess relationship between two numerical variables. For qualitative data, Pearson's Chi square, or Fisher-Freeman-Halton Exact tests were used to examine association between two variables. Receiver-operating characteristic (ROC) curve for predicting in-hospital 
mortality was generated from the data. Area under ROC curve (AUC), sensitivity, specificity, positive and negative predictive values (PPV, NPV) were calculated. Significance was adopted at $p<0.05$ for interpretation of results of tests (Dawson and Trapp, 2001).

\section{Results}

One hundred and eight patients were included in this study. Their ages ranged from 19 to 75 years with median age of 25.5 years. More than half of the studied patients were males $(55.6 \%)$ and most of them were from rural areas $(61.1 \%)$. All cases were exposed to $\mathrm{CO}$ through unintentional poisoning. The most common cause of $\mathrm{CO}$ poisoning recorded in this study was gas water heater $(53.7 \%)$, followed by fire accidents $(22.2 \%)$, domestic gas leakage $(20.4 \%)$, while $3.7 \%$ of patients were exposed to $\mathrm{CO}$ poisoning from motor vehicle exhaust in closed garage. The median duration of $\mathrm{CO}$ exposure was 4.3 hours with IQR; 2-8, and the median delay time was 3.8 hours $(\mathrm{IQR}=1-6)($ Table 2$)$.

Among the studied 108 patients; 20 patients $(18 \%)$ died in hospital (non-survivors group) and 88 patients survived (survivors group); of those who survived, $43 \%$ were recovered and $39 \%$ suffered from complications as demonstrated in figure (1). In addition, figure (2) revealed that disturbed memory and difficult speech were the most common complications as each of them was recorded in 12 patients $(11.1 \%)$, followed by personality changes and concentration deficits which occurred in 8 patients for each $(7.4 \%)$, gait disturbance was registered in 6 patients (5.6\%), while recurrent headache and insomnia occurred in 4 patients for each (3.7\%).
The median age of the patients who died was older than those who survived (30 years versus 25 years), however no statistical significant difference was detected between the two groups as regards age. Moreover, this study revealed that the median duration of $\mathrm{CO}$ exposure was significantly longer in nonsurvivors than in survivors ( 8 hours versus 4 hours; $p=0.017$ ). Similarly, the median delay time registered in non-survivors was significantly longer than that in survivors $(8$ hours versus 2.5 hours; $p<0.001$ ). On the other hand, there was no statistically significant difference between the two studied groups as regards gender, residence or source of $\mathrm{CO}$.

All patients in the non-survivors group were admitted to intensive care unit (ICU) and they needed assisted ventilation; while, 22.7\% of the survivors were admitted to ICU and only $6.8 \%$ of them needed assisted ventilation. Table (2) showed that there was statistical significant difference between the two studied groups regarding ICU admission and need for assisted ventilation $(p<0.001)$. Despite, the median hospital stay duration was longer in survivors group than in non-survivors group (72 hours versus 64 hours), however, no statistical significant difference could be detected between the two groups as regards hospital stay duration.

The current study revealed a statistical significant difference between the survivors and non-survivors regarding the values of the four studied scores; GCS, APACHE II, SAPS II, and REMS ( $<<0.001)$. The median of GCS in the survivors group was significantly higher than in the non-survivors group (12.5 versus 3.5), meanwhile, the medians of the other scores; APACHE II, SAPS II and REMS were significantly lower in the survivors than in the non-survivors $(5,13,2$ versus $28,70.5,17.5$ respectively; $\mathrm{p}<0.001)$ as demonstrated in table (3). 
The current study demonstrated negative significant correlations between GCS and delay time, duration of $\mathrm{CO}$ exposure and hospital stay duration. On the other hand, positive significant correlations were detected between the previously mentioned three parameters and each of APACHE II, SAPS II and REMS scores $(p<0.001$; Table 4$)$.

The results of analysis of ROC curve in the four studied scores were illustrated in table (5) and figure (3). All the studied scores had AUC above 0.9 - which indicates their being excellent predictors for in-hospital mortality in $\mathrm{CO}$ poisoned patients. Both the APACHE II and SAPS II scores had the best AUC (both were 0.995$)$, followed by REMS (0.993) then GCS (0.950). The AUC value of GCS was significantly lower than those of APACHE II, SAPS II and REMS scores; while differences between AUC of APACHE II, SAPS II, and REMS were not statistically significant.

The APACHE II - at a cutoff value $>17$ had $100 \%$ sensitivity, $97.7 \%$ specificity, $90 \%$ positive predictive value (PPV), and a negative predictive value (NPV) of $97.7 \%$. While, the SAPS II sensitivity, specificity, PPV, and NPV were $90 \%, \quad 100 \%, \quad 100 \%$, and $97.8 \%$ respectively, at a cutoff value $>53$. REMS had $90 \%$ sensitivity, $100 \%$ specificity, $100 \% \mathrm{PPV}$, and $97.8 \%$ NPV at cutoff value $>11$. Finally, the GCS had 100\% sensitivity, $90.9 \%$ specificity, $71.4 \% \mathrm{PPV}$, and $100 \% \mathrm{NPV}$ at a cutoff value $\leq 5$.

Table (1): The Glasgow Coma Scale (GCS)

\begin{tabular}{|c|c|c|}
\hline Feature & Scale response & Score \\
\hline Eye opening & $\begin{array}{l}\text { Spontaneous } \\
\text { To verbal stimuli } \\
\text { To pain } \\
\text { No response }\end{array}$ & $\begin{array}{l}4 \\
3 \\
2 \\
1\end{array}$ \\
\hline Verbal response & $\begin{array}{l}\text { Oriented } \\
\text { Confused conversation } \\
\text { Inappropriate words } \\
\text { Incomprehensible sounds } \\
\text { No response }\end{array}$ & $\begin{array}{l}5 \\
4 \\
3 \\
2 \\
1\end{array}$ \\
\hline \multirow{6}{*}{ Motor response } & Obey commands & 6 \\
\hline & Localize pain & 5 \\
\hline & $\begin{array}{l}\text { Flexion } \\
\bullet \text { Normal (withdrawal to pain) }\end{array}$ & 4 \\
\hline & - Abnormal (decorticate posturing) & 3 \\
\hline & Extension (decerebrate posturing) & 2 \\
\hline & No response & 1 \\
\hline
\end{tabular}

(Teasdale and Jennett, 1974) 
Table (2): Characteristics of survivors and non-survivors of the studied carbon monoxide poisoned patients $(\mathrm{n}=108)$

\begin{tabular}{|c|c|c|c|c|c|c|}
\hline & Variables & $\begin{array}{l}\text { Survivors } \\
\text { group } \\
(\mathbf{n}=\mathbf{8 8})\end{array}$ & $\begin{array}{l}\text { Non- } \\
\text { survivors } \\
\text { group } \\
(\mathbf{n}=\mathbf{2 0})\end{array}$ & $\begin{array}{c}\text { Total } \\
(n=108)\end{array}$ & Test of statistics & $\mathbf{p}$ \\
\hline \multirow{3}{*}{ Age (years) } & Range & $19.0-75.0$ & $21.0-61.0$ & $19.0-75.0$ & \multirow{3}{*}{$Z_{\mathrm{MW}}=1.649$} & \multirow{3}{*}{0.099} \\
\hline & Median & 25.0 & 30.0 & 25.5 & & \\
\hline & IQR & $23.0-37.0$ & $27.5-34.0$ & $23.0-37.0$ & & \\
\hline \multirow{2}{*}{ Gender } & Male & $52(59.1 \%)$ & $8(40.0 \%)$ & $60(55.6 \%)$ & \multirow{2}{*}{$\mathrm{X}^{2} \mathrm{ChS}=2.405$} & \multirow{2}{*}{0.121} \\
\hline & Female & $36(40.9 \%)$ & $12(60.0 \%)$ & $48(44.4 \%)$ & & \\
\hline \multirow{2}{*}{ Residence } & Rural & $52(59.1 \%)$ & $14(70.0 \%)$ & $66(61.1 \%)$ & \multirow{2}{*}{$\mathrm{X}^{2} \mathrm{ChS}=0.816$} & \multirow{2}{*}{0.366} \\
\hline & Urban & $36(40.9 \%)$ & $6(30.0 \%)$ & $42(38.9 \%)$ & & \\
\hline \multirow{4}{*}{ Source of CO } & Gas water heater & $48(54.5 \%)$ & $10(50.0 \%)$ & $58(53.7 \%)$ & \multirow{4}{*}{$\mathrm{X}^{2} \mathrm{FFH}=2.712$} & \multirow{4}{*}{0.419} \\
\hline & Fire accidents & $20(22.7 \%)$ & $4(20.0 \%)$ & $24(22.2 \%)$ & & \\
\hline & Domestic gas leakage & $18(20.5 \%)$ & $4(20.0 \%)$ & $22(20.4 \%)$ & & \\
\hline & Motor vehicles exhaust & $2(2.3 \%)$ & $2(10.0 \%)$ & $4(3.7 \%)$ & & \\
\hline \multirow{3}{*}{$\begin{array}{l}\text { Duration of CO } \\
\text { exposure } \\
\text { (Hours) }\end{array}$} & Range & $0.5-15.0$ & $4.0-8.0$ & $0.5-15.0$ & \multirow{3}{*}{$Z_{\mathrm{MW}}=2.387$} & \multirow{3}{*}{$0.017^{*}$} \\
\hline & Median & 4.0 & 8.0 & 4.3 & & \\
\hline & IQR & $1.5-6.0$ & $4.0-8.0$ & $2.0-8.0$ & & \\
\hline \multirow{3}{*}{$\begin{array}{l}\text { Delay time } \\
\text { (Hours) }\end{array}$} & Range & $0.5-36.0$ & $1.0-10.0$ & $0.5-36.0$ & \multirow{3}{*}{$\mathrm{Z}_{\mathrm{MW}}=4.734$} & \multirow{3}{*}{$<0.001 *$} \\
\hline & Median & 2.5 & 8.0 & 3.8 & & \\
\hline & IQR & $1.0-4.0$ & $6.0-8.0$ & $1.0-6.0$ & & \\
\hline \multirow{5}{*}{ Outcome } & ICU admission & $20(22.7 \%)$ & $20(100.0 \%)$ & $40(37.0 \%)$ & $\mathrm{X}^{2} \mathrm{ChS}=41.727$ & $<0.001^{*}$ \\
\hline & Need assisted ventilation & $6(6.8 \%)$ & $20(100.0 \%)$ & $26(24.1 \%)$ & $\mathrm{X}^{2} \mathrm{ChS}=72.339$ & $<0.001^{*}$ \\
\hline & $\begin{array}{l}\text { Hospital stay duration } \\
\text { (Hours); } \\
\text { Range }\end{array}$ & $12.0-144.0$ & $12.0-96.0$ & $12.0-144.0$ & \multirow{3}{*}{$Z_{\mathrm{MW}}=0.339$} & \multirow[t]{3}{*}{0.735} \\
\hline & Median & 72.0 & 64.0 & 72.0 & & \\
\hline & IQR & $12.0-96.0$ & $24.0-96.0$ & $12.0-96.0$ & & \\
\hline
\end{tabular}

n: number; IQR: interquartile range; CO: carbon monoxide; ICU: Intensive care unit; $\mathrm{X}^{2} \mathrm{ChS}$ : Pearson's Chi square test; $\mathrm{X}^{2} \mathrm{FFH}$ : Fisher-Freeman-Halton Exact tests; $\mathrm{Z}_{\mathrm{MW}}$ : Mann-Whitney test; * significant.

Table (3): Assessment of GCS, APACHE II, SAPS II and REMS in the studied carbon monoxide poisoned patients $(\mathrm{n}=108)$

\begin{tabular}{|c|c|c|c|c|c|c|}
\hline \multirow{3}{*}{$\begin{array}{c}\text { Assessment } \\
\text { scores }\end{array}$} & \multicolumn{4}{|c|}{ Groups } & \multicolumn{2}{|c|}{ Mann - Whitney test } \\
\hline & \multicolumn{2}{|r|}{$\begin{array}{l}\text { Survivors } \\
(\mathrm{n}=\mathbf{8 8})\end{array}$} & \multicolumn{2}{|c|}{$\begin{array}{c}\text { Non-survivors } \\
(\mathbf{n}=\mathbf{2 0})\end{array}$} & \multirow[t]{2}{*}{$\mathbf{Z}$} & \multirow[t]{2}{*}{$\mathbf{p}$} \\
\hline & Median & Interquartile range & Median & Interquartile range & & \\
\hline GCS & 12.5 & $8.5-15.0$ & 3.5 & $3.0-5.0$ & 6.415 & $<0.001 *$ \\
\hline APACHE II & 5.0 & $2.0-10.0$ & 28.0 & $27.0-30.0$ & 6.915 & $<0.001 *$ \\
\hline SAPS II & 13.0 & $11.0-24.0$ & 70.5 & $64.0-76.0$ & 6.912 & $<0.001^{*}$ \\
\hline REMS & 2.0 & $2.0-6.0$ & 17.5 & $16.0-18.0$ & 6.926 & $<0.001^{*}$ \\
\hline
\end{tabular}

n: number; GCS: Glasgow coma scale; APACHE II: acute physiology and chronic health evaluation score; SAPS II: simplified acute physiology score; REMS: rapid emergency medicine score; * significant. 
Table (4): Spearman's correlation between the four studied scores and delay time, duration of carbon monoxide exposure, and hospital stay duration

\begin{tabular}{|l|c|c|c|c|c|}
\hline \multicolumn{2}{|c|}{ Parameters } & GCS & APACHEII & SAPS II & REMS \\
\hline \multirow{2}{*}{ Delay time (hours) } & $\mathbf{r}_{\mathbf{s}}$ & -0.404 & 0.467 & 0.419 & 0.511 \\
\cline { 2 - 6 } & $\mathbf{p}$ & $<0.001^{*}$ & $<0.001^{*}$ & $<0.001^{*}$ & $<0.001^{*}$ \\
\hline $\begin{array}{l}\text { Duration of CO } \\
\text { exposure (hours) }\end{array}$ & $\mathbf{r}_{\mathbf{s}}$ & -0.487 & 0.518 & 0.436 & 0.509 \\
\cline { 2 - 6 } & $\mathbf{p}$ & $<0.001^{*}$ & $<0.001^{*}$ & $<0.001^{*}$ & $<0.001^{*}$ \\
\hline $\begin{array}{l}\text { Hospital stay } \\
\text { duration (hours) }\end{array}$ & $\mathbf{r}_{\mathbf{s}}$ & -0.459 & 0.377 & 0.380 & 0.426 \\
\cline { 2 - 6 } & $\mathbf{p}$ & $<0.001^{*}$ & $<0.001^{*}$ & $<0.001^{*}$ & $<0.001^{*}$ \\
\hline
\end{tabular}

$\mathrm{r}_{\mathrm{s}}$ : Spearman's correlation coefficient; CO: carbon monoxide; GCS: Glasgow coma scale; APACHE II: acute physiology and chronic health evaluation score; SAPS II: simplified acute physiology score; REMS: rapid emergency medicine score; * significant.

Table (5): Comparison of the assessment scores for prediction of in-hospital mortality in the studied carbon monoxide poisoned patients $(\mathrm{n}=108)$

\begin{tabular}{|l|c|c|c|c|}
\hline & GCS & APACHE II & SAPS II & REMS \\
\hline AUC & 0.950 & 0.995 & 0.995 & 0.993 \\
$\mathbf{9 5 \%}$ CI) & $(0.890-0.983)$ & $(0.958-1.000)$ & $(0.958-1.000)$ & $(0.954-1.000)$ \\
$\mathbf{p}$ & $<0.001^{*}$ & $<0.001^{*}$ & $<0.001^{*}$ & $<0.001^{*}$ \\
Cutoff value & $\leq 5$ & $>17$ & $>53$ & $>11$ \\
Sensitivity \% & 100.0 & 100.0 & 90.0 & 90.0 \\
Specificity \% & 90.9 & 97.7 & 100.0 & 100.0 \\
PPV \% & 71.4 & 90.0 & 100.0 & 100.0 \\
NPV \% & 100.0 & 97.7 & 97.8 & \\
\hline & GCS versus APACHE II $=0.005^{*}$ & & \\
p-value of & GCS versus REMS $=0.014^{*}$ & & \\
pairwise & GCS versus SAPS II $=0.005^{*}$ & & \\
comparisons & APACHE II versus REMS $=0.679$ & & \\
& APACHE II versus SAPS II $=1.000$ & & \\
& REMS versus SAPS II $=0.740$ & & \\
\hline
\end{tabular}

GCS: Glasgow coma scale; APACHE II: acute physiology and chronic health evaluation score; SAPS II: simplified acute physiology score; REMS: rapid emergency medicine score; AUC: area under the curve; CI: confidence interval; PPV: positive predictive value; NPV: negative predictive value;* significant. 


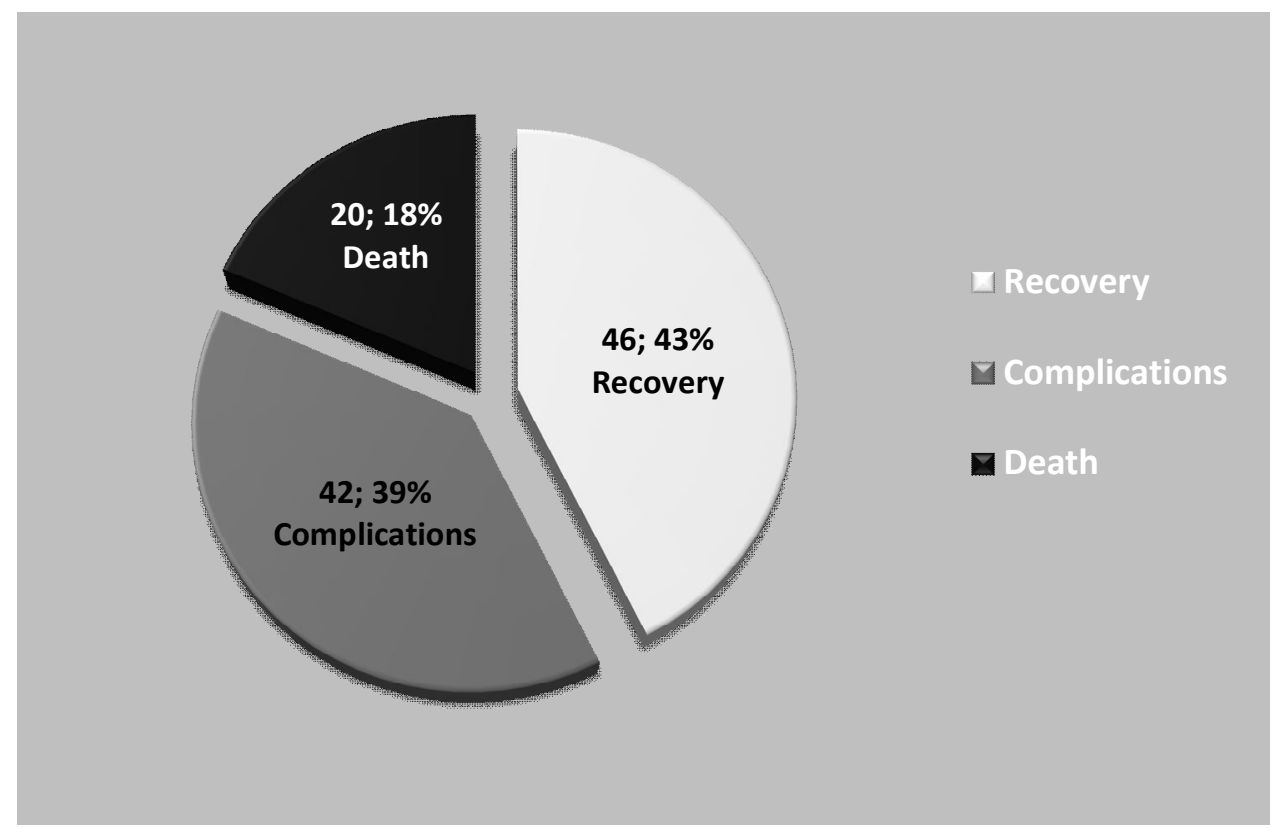

Fig. (1): Outcome of the studied carbon monoxide poisoned patients $(n=108)$.

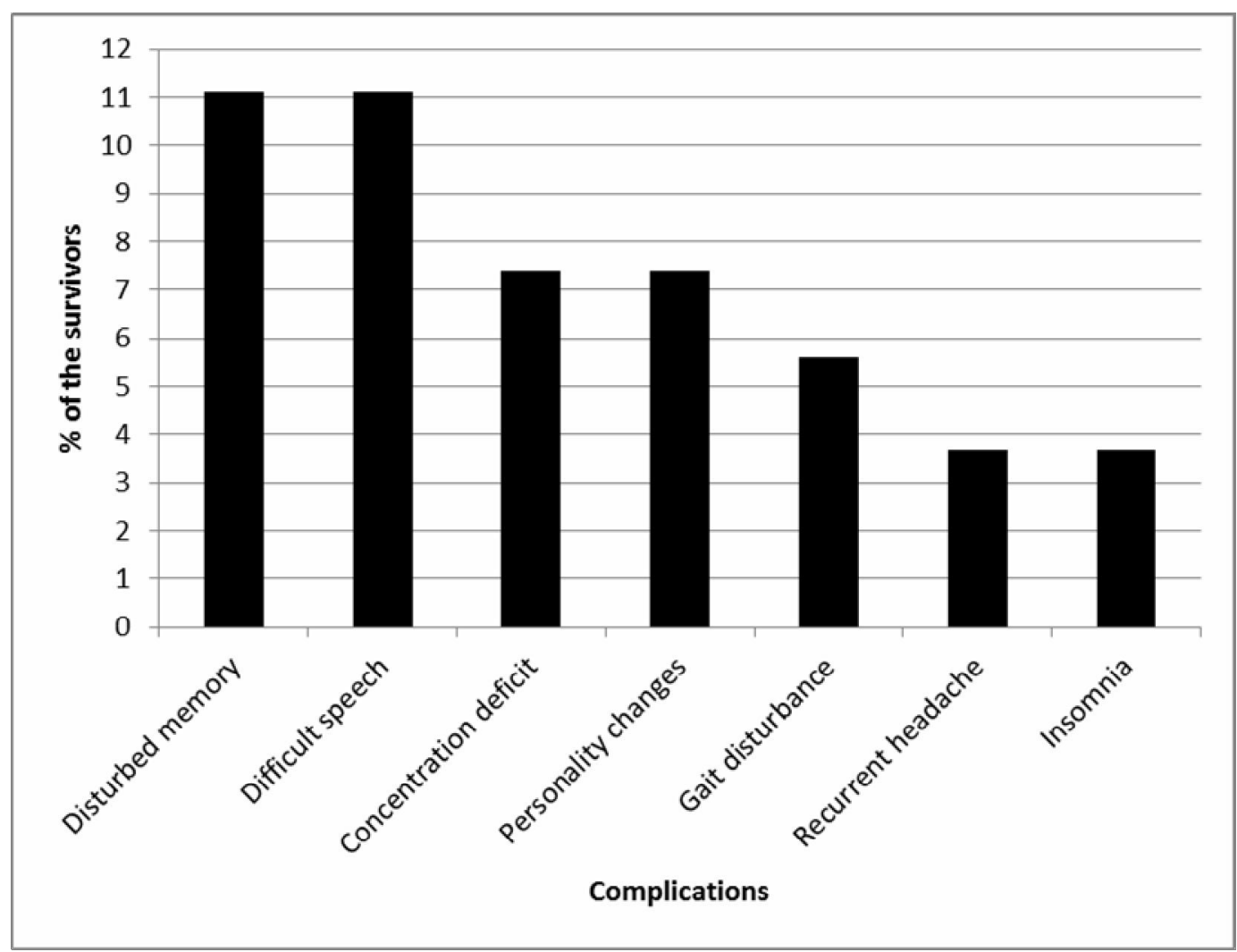

Fig. (2): Complications in the survivors group of the studied CO poisoned patients ( $n=88$ patients) 

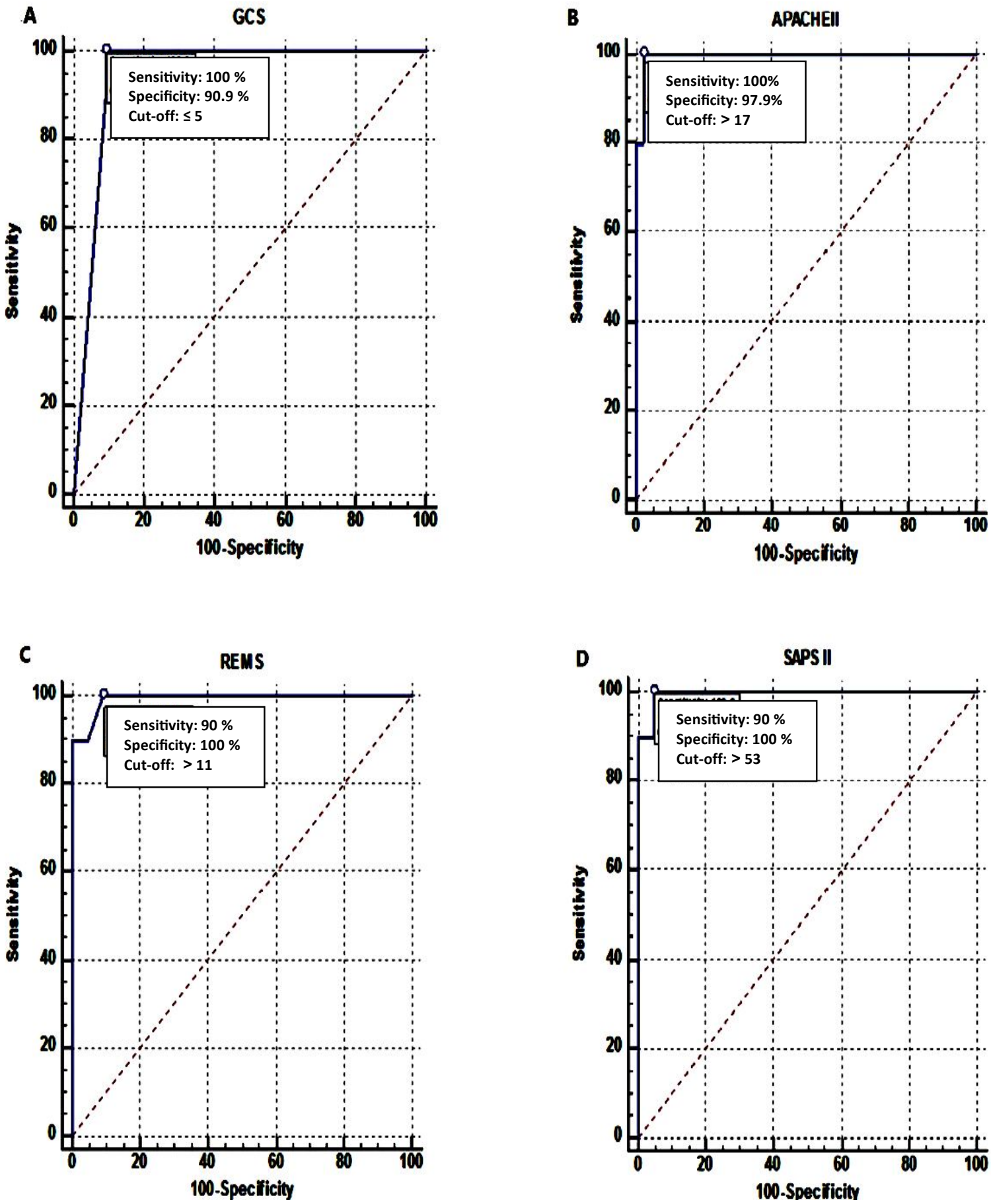

Fig. (3): ROC curves for GCS (A), APACHE II (B), REMS (C) and SAPS II (D) scores. GCS: Glasgow coma scale; APACHE II: Acute physiology and chronic health evaluation; REMS: Rapid emergency medicine score and SAPS II: Simplified acute physiology score. 


\section{Discussion}

In the present study, the ages of the studied patients ranged from 19 to 75 years with median age of 25.5 years. Similarly, Huang et al. (2017) reported high incidence of acute carbon monoxide (CO) poisoning among middle age patients. The reported predominance of males over females in the current study coincided with the findings observed by others studies (Shokrzadeh et al., 2013; Aldossary et al., 2015; Sikary et al., 2017). Meanwhile, it was contrary to the results of a study conducted in Morocco by Rebgui et al. (2013) who recorded higher incidence of $\mathrm{CO}$ poisoning in females. Our study revealed that $61.1 \%$ of cases were from rural areas; however, this was incompatible with the results of Farzaneh et al. (2015) who found that $54.3 \%$ of their patients were from urban areas.

All cases in this study were exposed to $\mathrm{CO}$ through unintentional poisoning and this could be attributed to the properties of $\mathrm{CO}$ being a colorless, odorless and poisonous gas which make it known as "silent killer". This result was in the same line with the results reported by Ghosh et al. (2016). However, carbon monoxide has been recognized as a method of intentional poisoning (Choi et al., 2014). Huang et al. (2017) recorded that intentional poisoning by charcoal burning was an important etiology of $\mathrm{CO}$ poisoning in Taiwan, and found that about one of five $\mathrm{CO}$ poisoning cases was a suicidal attempt.

The most common cause of $\mathrm{CO}$ poisoning recorded in this study was gas water heater $(53.7 \%)$ followed by fire accidents. Similar results were detected by Salameh et al. (2009) who studied the epidemiology of CO poisoning in Jerusalem and found that faulty gas heaters followed by fire accidents were the main sources of unintentional $\mathrm{CO}$ exposure. Also, Farzaneh et al. (2015) reported that water heater and gas heater were the most common causes of $\mathrm{CO}$ poisoning (48.6\% and $31.4 \%$ respectively). While, in another study conducted by Crowley et al. (2003) in Ireland, they found that fire was responsible for many $\mathrm{CO}$ poisonings.

The median delay time recorded in this study was 3.8 hours $(\mathrm{IQR}=1-6)$ which was comparable with $\mathrm{Ku}$ et al. (2015) who found that short period of time was recorded for referral of patients to the hospital (6-10 hours). The median duration of $\mathrm{CO}$ exposure in the current study was 4.3 hours which was close to the findings of Kim et al. (2018).

The present study showed that $18 \%$ of the patients died in-hospital, 43\% recovered and $39 \%$ suffered from complications which were mainly neurological. However, $\mathrm{Ku}$ et al. (2015) recorded lower mortality rate $(7.3 \%)$ and lower incidence of neurological sequelae $(9.1 \%)$ in their studied $\mathrm{CO}$ poisoned patients. The median age of the patients who died in our study was older than those who survived with no significant difference and this coincided with Cevik et al. (2006) who reported that mortality cases had significantly higher mean age than survivors.

Furthermore, statistical significant difference was detected between the two studied groups regarding ICU admission and need for assisted ventilation and this was in agreement with the results of Barghash and her colleagues (2017) who demonstrated that all mortality cases in their study were admitted to ICU and needed mechanical ventilation.

Moreover, the current study revealed statistical significant difference between survivors and non-survivors regarding the median duration of $\mathrm{CO}$ exposure and the median delay time. Also, it was demonstrated that delay time, duration of $\mathrm{CO}$ exposure and hospital stay duration had negative significant correlations with GCS and positive significant correlations 
with each of APACHE II, SAPS II and REMS scores.

This could be explained by the fact that late presentation to the hospital and prolonged exposure to the toxin are risk factors and associated with poor prognosis. Barghash et al. (2017) showed that prolonged delay time was one of the risk factors for poor prognosis in acute carbon monoxide poisoning. In addition, Kim et al. (2018) stated that increased $\mathrm{CO}$ exposure duration was associated with increased risk of acute brain injury occurrence. Also, it was reported that prolonged $\mathrm{CO}$ exposure duration and decreased consciousness (low GCS) were associated with increased risk of neurological sequelae (Kitamoto et al., 2016), increased risk of aspiration pneumonia and poor outcome (Sohn et al., 2017).

To the best of the authors' knowledge, this is the first study to compare simple physiological scores in the emergency department (GCS, APACHE II, SAPS II and REMS scores) as prognostic factors for inhospital mortality in $\mathrm{CO}$ poisoned patients. Regarding GCS in this study, the median GCS in the survivors group was significantly higher than in the non-survivors group. The GCS had a fair AUC, $100 \%$ sensitivity, $90.9 \%$ specificity, $100 \% \mathrm{NPV}$ and it had the least PPV (71.4\%) at a cutoff point $\leq 5$. These results were in the same line with that reported by Forsberg et al. (2012) who found that acutely poisoned patients with GCS $\square 7$ at admission had a mortality rate higher about seven times than the total hospital mortality rate. Also, Budhathoki et al. (2009) studied the outcome of poisoned children and revealed that GCS less than 8 was associated with higher mortality rates. However, Cattermole et al. (2009) recorded higher mean values of GCS $(10.7 \pm 4.9)$ in critically ill patients who needed ICU admission or died in emergency department.
The APACHE II score is a general mortality prediction model in critically ill patients (Strand and Flaatten, 2008). In the present study, patients of the non-survivors group had significantly higher APACHE II values than survivors (medians; 28 versus 5 respectively, $\mathrm{p}<0.001$ ). The APACHE II had the best AUC, at cutoff value $>17$, APACHE II had $100 \%$ sensitivity (it identified all dead cases in the studied sample), $97.7 \%$ specificity (it identified $97.7 \%$ of survivors), $90 \%$ PPV (90\% of patients with scores above the cut-off value died), and a NPV of $97.7 \%$ (97.7\% of patients who had score below the cutoff value survived). Mathai and Bhanu (2010) found that, survivors of aluminum phosphide (ALP) poisoned patients had significantly lower APACHE II score than non-survivors $(8.64 \pm 5.27$ versus $14.56 \pm 6.66$, respectively, $p=0.019$ ). Moreover, Louriz et al., (2009) revealed that APACHE II score was positively correlated with mortality in ALP poisoned patients.

Similar to APACHE II, SAPS II had significantly lower scores in the survivors than in the non-survivors (median was 13 versus 70 respectively). It also had the best AUC with sensitivity, specificity, PPV, and NPV were $90 \%, 100 \%, 100 \%$, and $97.8 \%$ respectively, at a cutoff value $>53$. Kim et al. (2008) mentioned that, APACHE II and SAPS II could be predictors of mortality in organophosphate poisoned patients.

In the current study, REMS score had higher values in non-survivors when compared to survivors (medians; 17.5 versus 2.00 respectively). It had a good AUC that was very close to both APACHE II and SAPS II, with $90 \%$ sensitivity, $100 \%$ specificity, $100 \%$ PPV, and $97.8 \% \mathrm{NPV}$ at cutoff value $>11$. These results coincided with the results detected by Olsson et al. (2004 b) who concluded that, REMS could be used as a good predictor of long term mortality in non-surgical patients admitted to emergency department, where non survivors 
had significantly higher scores than survivors. In addition, Cattermole et al. (2009) recorded significant increase of the mean values of REMS in patients admitted to ICU or died when compared to those who had better prognosis $(9.1 \pm 4.3$ versus. $6.1 \pm 4.0$, respectively).

\section{Conclusions}

In conclusion, the four studied scores (GCS, APACHE II, SAPS II and REMS) had good AUC above 0.9; but, the AUC of GCS was significantly lower than those of APACHE II, SAPS II and REMS scores; meanwhile, no significant differences were detected between AUC of APACHE II, SAPS II, and REMS. Moreover, the APACHE II, SAPS II and REMS have relatively close abilities to distinguish and estimate inhospital mortality of carbon monoxide poisoned patients. However, REMS is a simple, easy and rapid scoring system that does not consume time or require several laboratory variables which could be unavailable at admission. Hence, REMS seems to be more useful in predicting inhospital mortality in acute $\mathrm{CO}$ poisoning rather than more complicated scoring systems such as APACHE II and SAPS II.

\section{Limitations}

The main limitation of this study is the fact of being a single-center study with small sample size. In addition, $\mathrm{CO}$ poisoning is known to be responsible for many delayed complications especially neurological, however, we could not study those long-term complications or mortality rates.

\section{Recommendations}

Despite carbon monoxide poisoning is a common cause of morbidity and mortality worldwide, but scarce studies are available in the literature comparing the different scoring systems for early prediction of its outcome. Hence, further researches are required in this area. Also, more multi-centers studies are mandatory to compare between early and late scores of the various scoring systems to detect precisely the best scoring system that offers better prediction of $\mathrm{CO}$ poisoning outcome.

\section{References}

Aldossary, M.; Almadni, O.; Kharoshah, M.; et al. (2015): "Carbon monoxide toxicity in Dammam, KSA: Retrospective study". Egyptian Journal of Forensic Sciences, 5: 36-38.

Alter, S.M.; Infinger, A.; Swanson, D.; et al. (2017): "Evaluating clinical care in the prehospital setting: Is rapid emergency medicine score the missing metric of EMS? "Am. J. Emerg. Med., 35 (2):218221.

Aminiahidashti, H.; Bozorgi, F.; Montazer, S.H.; et al. (2017): "Comparison of APACHE II and SAPS II scoring system in prediction of critically ill patients' outcome". Emerg. (Tehran), 5(1):e4.

Barghash, S.; El-Sherif, H.; Salah El-Din, R.; et al. (2017): "The validity of poisoning severity score in acute carbon monoxide intoxicated patients". British Journal of Medicine \& Medical Research, 19 (5): 117.

Budhathoki, S.; Poudel, P.; Shah, D.; et al. (2009): "Clinical profile and outcome of children presenting with poisoning or intoxication: a hospital based study". Nepal Med. Coll. J., 11 (3): 170-175. 
Cattermole, G.N.; Mak, S.K.P.; Liow, C.H.E.; et al. (2009): "Derivation of a prognostic score for identifying critically ill patients in an emergency department resuscitation room". Resuscitation, 80 (9): 1000-1005.

Cevik, A.A.; Unluoglu, I.; Yantuali, S.; et al. (2006): "Interrelation between the poisoning severity score, carboxyhaemoglobin levels and in-hospital clinical course of carbon monoxide poisoning". Intern. J. of Clin. Pract., 60 (12):1558-1564.

Choi, Y.R.; Cha, E.S.; Chang, S.S.; et al. (2014): "Suicide from carbon monoxide poisoning in South Korea: 2006-2012". J. Affect Disord., 167: $322-325$.

Crowley, D.; Scallan, E.; Herbert, J.; et al. (2003): "Carbon monoxide poisoning in the republic of Ireland". IR. Med. J., 96 (3):83-86.

Dawson, B. and Trapp, R.G. (2001): Basic and Clinical Biostatistics. 3rd Edition, Lang Medical Book-McGraw-Hill, New York, P.P. 161-218.

Eizadi-Mood, N.; Sabzghabaee, A.M. and Khalili-Dehkordi, Z. (2011): "Applicability of different scoring systems in outcome prediction of patients with mixed drug poisoninginduced coma". Indian J. Anaesth., 55 (6):599-604.

El-Masry, M.K. and Tawfik, H.M. (2013): "2011 Annual report of the poison control centre of Ain Shams University Hospital, Cairo, Egypt". Ain Shams Journal of Forensic Medicine and Clinical Toxicology, 20: $10-17$.

El-Sarnagawy, G.N. and Hafez, A.S. (2017): "Comparison of different scores as predictors of mechanical ventilation in drug overdose patients". Hum. Exp. Toxicol, 36 (6): 539-546.

Farzaneh, E.; Seraji, F.N. and Valizadeh, B. (2015): "Epidemiology of carbon monoxide gas poisoning deaths in Ardabil city, 2008-13". Int. J. Res. Med. Sci., 3 (4):929-932.

Forsberg, S.; Hojer, J. and Ludwigs, U. (2012): "Hospital mortality among poisoned patients presenting unconscious". Clin. Toxicol. (Phila), 50 (4):254-257.

Ghosh, R.E.; Close, R.; McCann, L.J.; et al. (2016): "Analysis of hospital admissions due to accidental non-fire-related carbon monoxide poisoning in England, between 2001 and 2010". J. Public Health (Oxf.), 38 (1):76-83.

Ha， D.T.; Dang， T.Q.; Tran, N.V.; et al. (2015): "Prognostic performance of the rapid emergency medicine score (REMS) and worthing physiological scoring system (WPS) in emergency department". Int. J. Emerg. Med., 8:18.

Huang, C.C.; Ho, C.H.; Chen, Y.C.; et al. (2017):"Demographic and clinical charateristics of carbon monoxide poisoning: Nationwide data between 1999 and 2012 in Taiwan". Scand. J. Trauma Resusc. Emerg. Med., 25:70.

Kelly, C.A.; Upex, A. and Bateman, D.N. (2004): "Comparison of consciousness level assessment in the poisoned patient using the alert verbal painful unresponsive scale and the Glasgow coma scale". Ann. Emerg. Med., 44: $108-113$.

Kim, H.; Han, S.B.; Kim, J.S.; et al. (2008): "Clinical implication of acetyl cholinesterase in acute organ ophosphate poisoning". J. Korean Soc. Clin. Toxicol., 6: 25-31. 
Kim, Y.H.; Yeo, J.H.; Kang, M.J.; et al. (2013): "Performance assessment of the SOFA, APACHE II scoring system and SAPS II in intensive care unit organophosphate poisoned patients". J. Korean Med. Sci., 28 (12):1822-1826.

Kim, Y.J.; Sohn, C.H.; Seo, D.W.; et al. (2018): "Clinical predictors of acute brain injury in carbon monoxide poisoning patients with altered mental status at admission to emergency department". Acad. Emerg. Med., available at https://doi.org/10.1111/ acem. 13510 .

Kitamoto, T.; Tsuda, M.; Kato, M.; et al. (2016): "Risk factors for the delayed onset of neuropsychologic sequelae following carbon monoxide poisoning". Acute Med. Surg., 3 (4):315-319.

Knaus, W.A.; Draper, E.A.; Wagner, D.P.; et al. (1985): "APACHE II: a severity of disease classification system". Crit. Care Med., 13: 818-829.

Ku, C.H.; Hung, H.M.; Leong, W.C.; et al. (2015): "Outcome of patients with carbon monoxide poisoning at a FarEast Poison Center". PLoS. ONE, 10 (3): 1-10.

Le Gall, J.R.; Lemeshow, S. and Saulnier, F. (1993): "A new simplified acute physiology score (SAPS II) based on a European/North American multicenter study". JAMA., 270 (24):2957-2963.

Louriz, M.; Dendane, T.; Abidi, K.; et al. (2009): "Prognostic factors of acute aluminum phosphide poisoning". Indian J. Med. Sci., 63:227-234.

Mathai, A. and Bhanu, M.S. (2010): "Acute aluminium phosphide poisoning: Can we predict mortality?" Indian J. Anaesth., 54 (4):302-307.
Nazari, J.; Dianat, I. and Stedmon, A. (2010):"Unintentional carbon monoxide poisoning in Northwest Iran: A 5-year study". J. Forensic Leg. Med., 17 (7):388-391.

Neil, B. and Hampson, M.D. (2011): "Residential carbon monoxide poisoning from motor vehicles". Am. J. Emerg. Med., 29:75-77.

Ng, P.C.Y.; Long, B. and Koyfman, A. (2018): "Clinical chameleons: an emergency medicine focused review of carbon monoxide poisoning". Intern. Emerg. Med., 13 (2):223-229.

Olsson, T.; Terent, A. and Lind, L. (2004 a): "Rapid emergency medicine score: a new prognostic tool for in-hospital mortality in nonsurgical emergency department patients". J. Intern. Med., 255 (5): 579587.

Olsson, T.; Terent, A. and Lind, L. (2004 b): "Rapid emergency medicine score can predict long-term mortality in nonsurgical emergency department patients". Acad. Emerg. Med., 11 (10): 1008-1013.

Rebgui, H.; Hami, H.; Ouammi, L.; et al. (2013): "Epidemiological and clinical aspects of carbon monoxide poisoning in Morocco: Case of oriental region". Am. J. Adv. Sci. Res., 1 (10):348-355.

Rose, J.J.; Wang, L.; Xu, Q.; et al. (2017): "Carbon monoxide poisoning: pathogenesis, management, and future directions of therapy". Am. J. Respir. Crit. Care Med., 195 (5):596-606.

Salameh, S.; Amitai, Y.; Antopolsky, M.; et al. (2009): "Carbon monoxide poisoning in Jerusalem: epidemiology and risk factors" . Clin. Toxicol. (Phila)., 47 (2): 137-141. 
Shokrzadeh, M.; Poorhossein, M.; Nasri, N.A.; et al. (2013): "Epidemiologic study of mortality rate from carbon monoxide poisoning recorded in Mazandaran department of forensic medicine, 2009- 2011". J. Mazandaran Univ. Med. Sci., 23 (99):86- 95.

Sikary, A.K.; Dixit, S. and Murty, O.P. (2017): "Fatal carbon monoxide poisoning: A lesson from a retrospective study at all India institutes of medical sciences, New Delhi". J. Family Med. Prim. Care, 6 (4):791-794.

Sohn, C.H.; Huh, J.W. and Seo, D.W. (2017): "Aspiration pneumonia in carbon monoxide poisoning patients with loss of consciousness: Prevalence, outcomes, and risk factors". Am. J. Med., 130 (12):1465.e21-1465.e26.

Strand, K. and Flaatten, H. (2008):"Severity scoring in the ICU: a review". Acta. Anaesthesiol. Scand., 52 (4):467-478.

Tabrizian, K.; Khodayari, H.; Rezaee, R.; et al. (2018):"Magnesium sulfate protects the heart against carbon monoxideinduced cardiotoxicity in rats". Res. Pharm. Sci., 13 (1): 65-72.

Teasdale, G. and Jennett, B. (1974): "Assessment of coma and impaired consciousness: a practical scale". Lancet, 304: $81-84$ 


\section{تقييم بعض أنظمة التسجيل فى التنبؤ بمعدلات الوفيات في مرضى التسمم الحاد بأول أكسيد الكربون}

\section{دعاء محمد الفرباوى و هبه كامل خليفة}

قسم الطب الثرعى والسموم الإكلينيكية ـ كلية الطب - جامعة طنطا

يعرف غـاز اول اكسيد الكربون بالقاتل الصامت ، ويعتبر التسمم بـأول اكسيد الكربون واحدا من أهم أسباب الوفاة بالتسمم فى مصر. وتهدف هذه الدر اسـة إلى تقييم بعض أنظمـة التسجيل وهم (مقيـاس جلاسكو للغييوبـة و ومقيـاس أباتشي الثاني ومقياس سيبس الثانى و مقيـاس ريمس) فى التنبؤ بمعدلات الوفيات داخل المستشفيات فى مرضي التسمم الحاد بأول أكسيد الكربون. و قد تم إجراء هذه الدر اسة على مائة وثمانبة مريضا من مرضـى التسمح الحساد بـأول أكسيد الكربون حيث تم جمـع البيانـات الاجتماعيـة و الديمغر افية وبيانـات خاصـة بالتسمم لكل مريض، وكذلك تم إجر اء الفحص الإكلينيكى وحساب مجموع نقاط أنظمـة التسجيل الأربعة لكل مريض عند دخولـه المستشفى ومـن ثم تم تقسيم الحسالات الـى مجمو عتين ( مجمو عـة المتعـافين بعد التسمم و مجموعـة الوفيـات). و قـد اعتمـد التقيهيم بـين الأنظمـة الأربعـة على اسـتخدام منحنى روك وحسـاب الانحـدار

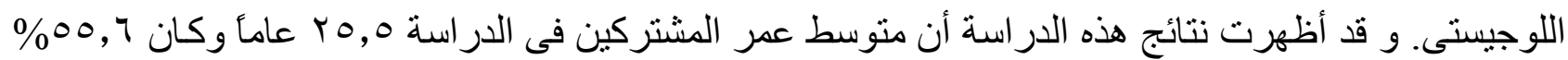
ذكور و 1, آ7\% من الريف. كما أظهرت النتائج أن جميع الحالات كانت نتيجه التسمم العرضى بغاز أول أكسيد

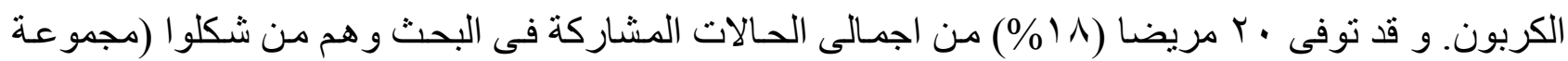
الوفيات). وتبعا لتحليل نتائج الانحدار اللوجيستى للمرضسى فقد وجد أن كلا من نظام الاباتشي الثانى وسيبس الثانى قد سجلا أفضل معدل انحدار لوجيستى يتبعهم نظام ريمس ثم مقياس جلاسكو وقد وجد ان هناك فرق ذو دلالة أحصائية بين معدل الانحدار اللوجيستى لمقياس جلاسكو (أقل معدل) و معدلات الانحدار اللوجيستى لباقى أنظمة التسجيل في حين لم تتو اجد هذه الدلالة الاحصائية بين أنظمة الاباتثي الثانى ،السيبس الثانى و ريمس من حيث قيمة الانحدار اللوجيستى لكلٍ منهم. وقد خلصت هذه الدراسة إلى أن نظام ريمس بيدو أكثر فائدة في التتبؤ بالوفيات داخل المستشفى في حـالات التسمم الحـاد بـأول أكسيد الكربون، حيث أنه نظـام تسجيل بسيط وسـل وسريع بدلا من أنظمة التسجيل الأكثر تعقيدًا مثل نظامى الاباتثي الثانى و السيبس الثانى. 